The Mental Training of a Traveller

Authors(s): Viscount Bryce

Source: The Geographical Journal, Vol. 45, No. 2 (Feb., 1915), pp. 110-122

Published by: geographicalj

Stable URL: http://www.jstor.org/stable/1780248

Accessed: 27-03-2016 23:21 UTC

Your use of the JSTOR archive indicates your acceptance of the Terms \& Conditions of Use, available at

http://about.jstor.org/terms

JSTOR is a not-for-profit service that helps scholars, researchers, and students discover, use, and build upon a wide range of content in a trusted digital archive. We use information technology and tools to increase productivity and facilitate new forms of scholarship. For more information about JSTOR, please contact support@jstor.org.

The Royal Geographical Society (with the Institute of British Geographers), Wiley are collaborating with JSTOR to digitize, preserve and extend access to The Geographical Journal

http://www.jstor.org 
daily recurrence over a month and a half. The journey described would have been a great trial to the hardiest explorer; that it has been accomplished by an eminent statesman like Mr. Roosevelt, who has reached middle life, is a most remarkable feat. I am sure we all congratulate Mr. Roosevelt upon it, and we hope that when he next undertakes a similar journey he will come here and give us an account of it.

Mr. Roosevelt : I wish to add one word. It would be more technically accurate to say that we were the first explorers, not the "discoverers," of the river, just as was true of those who first explored the upper Nile and Congo. We "discovered" the mouths of the various tributaries, which we did not explore; we explored the main river, of which the head and mouth were known, although there was no knowledge that they were the head and mouth of one river.

\section{THE MENTAL TRAINING OF A TRAVELlER.*}

\section{By the Right Hon. VISCOUNT BRYCE, O.M.}

WHEN the President asked me to give you an address this winter, I felt it impossible to refuse a request coming from so old and valued a friend as your President has been to me; but I did feel some little difficulty about a subject, because it occurred to me that on an occasion like this you might naturally wish that every address should be connected in some way with the geography of the war which is now proceeding in different parts of Europe and Asia, and, indeed, in Africa and the Pacific also. But he observed to me in reply, and it seemed to me his answer carried sense and reason with it, that it was not desirable that, when we were doing nothing but talk about the war on every other occasion from morn till night, the meetings of the Geographical Society should also be occupied with that subject only. In fact, he observed it is better that now and then our minds should have a little respite and rest from the one engrossing topic. So it struck me that since we cannot travel ourselves this winter, perhaps not even next spring or summer, we might, at any rate, occupy ourselves by thinking about travel. You recollect how Tennyson says that the Knights of the Round Table, when they were not engaged in a tournament, used to "walk about the gardens and the groves at Camelot and delight their souls with talk of knightly deeds." So we may occupy ourselves this winter at the rare moments when our minds can have rest from the obsessing topic in thinking about travel, in recording what we have gained through travel, and in suggesting to one another what it is that travel has to give. Hence I have chosen a topic which rose out of my conversation with your President; namely, how it is that we ought to prepare ourselves to get the maximum of enjoyment and of benefit from our habits of travel. And in speaking of travel $\mathrm{I}$ am not to-night thinking of exploration. It is, of course, primarily for the encouragement of exploration, and for hearing the accounts of exploration which the explorer is able to give, that this Society exists. Its most famous deeds have been those done in encouraging travel, and its most

* Royal Geographical Society, November 23, 1914. 
brilliant evenings have been those in which some man, returned from a journey of discovery in remote and dangerous regions, has recounted his achievements. All I propose to do to-night is of a very much humbler kind. It is to suggest how we may best fit ourselves and equip ourselves, to get the greatest possible pleasure and the greatest possible profit out of journeys which are not journeys of exploration-or only here and there journeys of exploration-but which in the main pass over ground that has been traversed before, but is susceptible of some little further cultivation, and, at any rate, of yielding something of value to ourselves as individuals. There is, indeed, not very much exploration on a large scale left to be done now, though it might surprise you to hear that there are places within the British dominions which no foot has ever traversed, and which may remain untraversed for a long time to come. Curiously enough, I struck two such places two years ago in New Zealand and Tasmania. They told me that there are parts of the west coast of New Zealand where the natural difficulties of precipices and profound gorges are so great that nobody has ever crossed from east to west, and that passes remain to be discovered by the daring climber which may prove to be practicable methods of getting through from some valley in the west coast to a valley on the eastern slope. Still more in Tasmania, a little bit of an island with no mountains of great height, there are tracts lying along the west coast which nobody has ever traversed. There are, here and there, stretches of 30 or 40 miles, measured north and south, entirely unknown, tracts that have remained unexplored ever since we took possession of the island. So even in regions close to civilization something new still remains to be done.

What I wish to dwell upon to-night is the way in which we may study and learn with a view to travel, in such wise as to derive a greater amount of benefit from our travel than it is possible for any one going without any previous preparation to obtain. It is very much like going into a picture-gallery. If a man enters the finest picture-gallery in Europe knowing nothing at all about the painters, whose work is there stored, their dates, the schools they belonged to, or the subjects they painted, he will derive very little benefit, and will carry away a most confused impression; but a little preliminary study will enable him to appreciate and enjoy pictures in a way which will be profitable all the rest of his life.

So it is when we enter the vast gallery of Nature. If we start to travel with a certain amount of preliminary knowledge, our travels repay us more and more at every step. The three things we ought to carry with us in order to learn and to profit are these: first of all, we ought to know what to look for; secondly, how to observe; and thirdly, how to reflect upon the things we do observe. Thus, also, the pleasures of travel are three : in the first place, the pleasure of observation, that which arises in the exercise of the faculty of observing; secondly, the pleasure of reflecting upon and generalizing from what we have observed; and thirdly, 
the pleasure of memory, because it often happens that the pleasure of travel is greater in recollection than at the actual moment. The traveller may be under a severe stress; he may be suffering some grievous hardship, or even sickness ; he may have what is even worse, the disappointment of being forced to hasten on when he desires to examine some spot more carefully. But long afterwards he can recall what he has seen and done; he can call up the impressions and meditate upon them; he can visualize a long series of scenes, and, still better, can talk them over with, and draw further light from, those who have had a similar experience. Now, the observing faculty which one exerts in travel naturally applies itself to two things. One is Nature, and the other comprises Man and all the works of man. Let me begin with the observation of nature, and you will pardon me if I run very rapidly over a number of things which it is interesting and profitable to observe, because every traveller has his own tastes, and there are many different sorts. I should like to cover as many fields of taste as possible, in the hope of striking now and then a more specially responsive chord.

Let us begin with the Stars, because one has much more opportunity of observing stars in travel than at any other time. We have more time, and whereas our own skies are familiar, the constellations visible when we are away from our own latitudes have the charm of novelty. There were of old, in the days when men sought for Final Causes, many lines of speculation as to the use of the stars, and why they were planted where they are. The oldest, which you will find in the ancient Greek poets, is the agricultural theory that they were created in order to tell men of the passage of seasons, and to indicate when the cultivator should sow and when he should reap. The second theory was they were set on high in order to furnish a means of foretelling the fate and fortunes of mankind, and upon this basis there was reared the science of Astrology, not yet quite extinct, for it is practised as a gainful art in San Francisco. The third theory was that they were useful for navigation, and this view has continued to hold its ground, for the stars are almost as valuable for navigation to-day as they were to the primitive Phœnician navigator who set out from Sidon in his ship bound for distant Tartessus or the tin-bearing coast of Cornwall. And lastly, we have within our own time discovered a new use for the stars, for by means of solar chemistry and the employment of the spectroscope we have discovered for the first time elements which chemistry has been subsequently able to identify as present in our own Earth. A fifth use the stars have is to add to the pleasures of travel, because when a voyage takes one down to or across the equator, or when in the southern hemisphere one traverses such a wilderness as the African Karroo, or passes over the deserts of South America, both of them exceedingly dry regions, where the air is exceptionally bright and clear, the pleasure of regarding the stars is one of the greatest pleasures travel can give. 
You recollect, I dare say, that in the account which Dante gives of the imaginary southward voyage of Ulysses the only geographical indication is that the son of Laertes and his companions when they started on that voyage of discovery which ended the career of the famous hero, came, after a time, to a part of the ocean where other stars began to appear. "And now," says the hero to the poet in the nether world, "now all the stars of the other pole appeared, and our own was sunk so low that it rose no more above the surface of the sea." * There the poet, without any experience himself, for he had never been south of his own Italy, felt with the instinct of genius what would be for any one who penetrated far to the south, one of the most striking features of the journey.

Next comes meteorology, and with it we may think also of ocean currents as being phenomena which it is a great and novel pleasure to study in the course of a long voyage. As many of you know, such a voyage is apt to be a little monotonous; but if you have the opportunity of passing through parts of the ocean where you have never been before, and where you find the phenomena both of air currents and of water currents different from those of our own North Atlantic, there is a constant interest in observing these phenomena, and of making the acquaintance of the captains and officers of the ship, who are able to give you information on these things, information which seems far more fresh and vital than when you read it even in the best book. However, I need say the less about this because in the volume called 'Hints to Travellers,' to which you, Mr. President, have made valuable contributions, you will find these subjects very fully and clearly treated, and indications given of the kinds of thing one ought to observe. I was very much struck, in making a voyage along the coast of South America, by encountering a current whose enormous importance $I$ had never realized until I found it obliged passengers to wrap themselves in great-coats on the equatorthat is the great Antarctic or so-called Humboldt current, which drifts up from the south and runs along the west coast of South America. We are all familiar with our old friend, the Gulf Stream, who is, indeed, so familiar that now, we are told, it is the fashion to say that quite too much has been made of him; but very few of us have realized that the importance of the Antarctic current is almost as great, although its effects are not so directly perceived to be beneficent as are those of the Gulf Stream.

Now I approach the most important part of our subject, because it is one which admits of very various forms of observation. It is the study of the surface of the Earth and of scenery. Whatever else we travel for, we all do so, at least in part, for the sake of observing scenery, and few can appreciate scenery to the full, or get the real enjoyment of it, without a strong desire to understand the elements of which scenic beauty consists. Of these elements the chief are those given by Geology. When

* Dante, Inferno, canto xxvi. 1. 127.

No. II.-FEBRUARY, 1915.] 
I name that science, do not suppose that I am going to suggest to any of you that a scientific knowledge of geology is in any way essential to the traveller. I am thinking of something far simpler and more easy of attainment than the scientific mastery of geology. It has become now a very elaborate science, which has ramified out into many branches, and grown quite large enough to occupy the whole of a man's energies. What I mean is very much less than that. I refer to those elements of the knowledge of the structure and formation of the Earth which are directly connected with scenery: what one may call the composition of the Earth as regards its substance and materials, and its structure as respects the succession of strata and the forms of the rocks which rise in eminences from the surface. These things interest the naturalist because the character of the surface and the rocks affect the vegetation and, iudurectly, the animals; they interest the painter because it is his business to portray beautiful and varied landscapes; they interest the climber because his object is to get as high as he can upon mountains, and in order to know how to climb any particular kind of mountain, he will profit very much by his knowledge of the particular kind of rock of which it is composed, as I shall try to explain to you presently. And lastly, apart from all these specialists, there is the lover of beauty, and the poet, who desires to derive inspiration from nature. From all these points of view, whatever enables us to increase our power of grasping the quality and charm of scenery and carrying it in our memory is an addition to our capacity for enjoyment. I am not suggesting anything that requires a great amount of study. What the traveller needs is something like the gift for catching the type of scenery which a great painter possesses. Many of you are familiar with the landscapes of Turner. Has it ever occurred to you that Turner is one of the very few landscape painters from whose landscapes you can generally perceive what is the rock he is painting? If you go to his pictures you can almost always tell whether the mountain he is delineating is a limestone, or granite, or sandstone, or a slate mountain, because he had the gift of precise discriminative sight, and took pains to catch the exact character of the rock and render it faithfully in respect both of colour and of line. The same is true of Titian. Any one who had ever seen one of the dolomitic mountains of Southern Tyrol would be able to recognize them from Titian's backgrounds. If you were set down before one of these Titian landscapes and did not know where the scene represented was situated, any one who had climbed among the valleys between the Pusterthal and the plains of Venetia would recognize the scene as belonging to the Dolomite country. Now the basis of this sort of knowledge which geology can give to help our appreciation of scenery may be said to reside in four things. In the first place, in a knowledge of the substance of the rock of which the hills are composed; secondly, in a knowledge of the series or succession of the different strata one above another; thirdly, in a knowledge of the processes by which 
the hills and mountains were raised; and fourthly, in a knowledge of the later process by which, after the raising had been completed, the mountains and hills were carved into the present shapes in which we now have them; that is to say, the processes of elevation and denudation. These four things are pieces of knowledge which a limited amount of geological study would be sufficient to give, and they would suffice to help a man to appreciate and enjoy the scenery of a mountainous country. One might acquire the elements of such knowledge in a course of five or six lectures. It is not always easy to find just these elements in the treatises. If you go to a manual of geology it tells you an enormous number of things which tax your memory and intelligence, and which you want explained to you by a teacher-in fact, there is much which it is hard to grasp unless you go out on geological excursions and see the natural sections and examine the rocks. Without that you cannot follow what the manual gives you. But the kind of knowledge I suggest might be got from a few lectures illustrated by views and by sections to show the way in which one rock is superimposed upon another, followed, if possible, by some excursions with guidance. Turner, however, discerned the character of mountain scenery without any geological knowledge at all by his inborn gift of seeing the actual and exact nature of things.

What I desire to convey may become clearer by showing you at this stage a few slides which the President has been kind enough to look up for me. From these you will see what are the characteristic forms which particular rocks assume in mountains. [A number of slides were here shown to illustrate the varieties of mountain form which are characteristic of certain rocks, especially those characteristic of gneiss, of granite, of mica schist and slate, of sandstone, of limestone, and of the more modern volcanic rocks. The views were taken from Ruwenzori in Central Africa, from the Caucasus, the Himalayas, the Alps, Greenland, Snowdon, in Wales, North America (the Grand Canyon of the Colorado river), South Africa (Table mountain), East Africa (Mount Kenia), Japan (Fujiyama), and the Hawaiian islands (crater of Kilauea). Remarks were made on the comparative difficulties of rock-climbing in gneiss and in limestone, the former rock often looking easier, and the latter looking more difficult than each respectively proved to be. Some account was given of the Colorado canyon and of the remarkable volcano of Kilauea, with its constantly boiling lake of liquid lava, out of which there rise frequent jets which appear as fountains of fire, but are really gigantic bubbles of steam spurting out red-hot lava.] Thirty years ago one could sit on the edge of this lake and watch its glowing surface broken by these fountains rising into the air, but now it is said that the level of the liquid lava has sunk into a pit, so the sight is less striking. It is quite possible, however, that it may rise again, for Kilauea has frequently changed since it was first observed more than a century ago. 
Many are the ways in which the character of rocks and mountains has affected history, and before quitting this part of the subject I may mention one or two which bear upon the operations of war. The great wars have usually been fought in level countries, such as Lombardy and Belgium, and such is the case to-day, except as regards the Russian campaign in Armenia, and the skirmishes we hear of between Russian and Austrian troops in the passes of the mountains between Galicia and Hungary, usually called in our maps the Carpathians. A study of campaigns carried on in mountain countries leads to conclusions which are not generally known, but become obvious enough when the physical conditions are realized. It is not usually the highest ridges or the central watershed which an army preparing itself to resist an expected attack finds it most necessary to hold or most easy to defend. The lower slopes and the points where tiue valleys open out from the mountains are really of more consequence. It often happens that the main central ridge of the mountain and the watershed where passes cross it are comparatively easy and open, and over and over again ridges not reaching the line of perpetual snow have been scaled up pretty steep slopes and across the high ridges, and the defending party has been driven back. On the other hand, when a mountain mass has in the slopes where it descends towards the plains narrow gorges with precipitous walls, gorges hollowed out by streams and which are so narrc ir as to be easily defensible, they become points which it is essential for the defending army to hold, and where the invader may not cnly be stopped, but stopped to his own great inconvenience and possible danger, becaus. he may find himself in the difficulty of being unable to obtain supplies in a waste and thinly peopled region. The best illustration of that maxim was to be found in the campaign of the famous Russian general, Suvarov, in 1799, when he, coming up from Italy, attacked the French and drove them over the pas of the Gothard and down the valley of the Reuss till he came near the Bay of Uri where the Reuss enters the Lake of Lucerne. There he found that the precipices which enclose the lake checked his advance, for the $\mathrm{Fr}^{\prime}$ ach had carried off all the boats; he was obliged to turn up a lateral valley to the east. He crossed the comparatively easy pass of the Kinzig Kulm and penetrated into the valley of Schwyz. There he became again entangled in the lower gorges, was met and stopped by the French, and could not fight his way through. He then turned east again and crossed a third pass, the Prägel, to the valley of Glarus. There again he was met by a French force guarding the narrow exit from the valley and was unable to break through. At last he was obliged to turn back southwards and cross a high pass where he was not opposed at all because nobody was guarding that side. So he got into the broader valley of the Vorder Rhine, where he was able to halt and rest his sorely reduced forces, because no Frenchmen were looking for him there. The campaign had failed, because while he had successfully forced his way across the main chain of the Alps he had been unable to force the exits from the valleys. A general who was 
content simply to look at the map might naturally think his chief difficulty would be to cross the highest ridges, but in fact it is not there that the pinch generally comes. Thus a knowledge of rocks and their structure and of mountain forms may become of importance to the military strategist as well as to the painter or the lover of scenery.

May I give you one curious other little instance of the way in which geology comes in to explain a remarkable incident in a famous war. Those of you who have read the account given by Thucydides of the siege of Syracuse by the Athenians will remember how he mentions that when the Athenians determined to try to storm a line of cliffs which formed a natural defence of the city upon the north side, there was only one place where they could get up the precipitous face. Whoever walks along that line of cliffs, which is singularly continuous though low, as is often the case with a limestone cliff, will find there is still only one place where a large attacking party could mount. There are several places where a single active climber can scramble up, but only one where there is a fairly wide break in the line of cliff available for a body of men. Now that particular point at which the only easily passable breach in the cliff occurs is the point where the cliff has been cut through by what geologists call a dyke of intrusive igneous rock. There is a gresst deal of igneous rock all over Eastern Sicily. Now this intrusive dyk ${ }^{\circ}$. has itself become decomposed. Nearly all of it having rotted away, there has been left a comparatively gentle and easy passage upwards from the slope belnw the cliff to the plateau above which gave access to the city behind. It was my luck to see in South Africa a place where the same thing had happened. There is a sandstone mountain in Basutoland, in South Africa, called Thaba Bosiyo, which some eighty years ago was the great stronghold of the Basuto chief, Moshesh, who for a long time defied the armies of the Dutch farmers of the Orange Free State. They waged lo.2g wars against him, and in one of their invasions the commander determined to storm the heights of Thaba Bosiyo where Moshesh had his kraal. The mountain is a long tableland encircled by sandstone precipices, but through these precipices there is just one practicable passage up to the top of the hill. The Dutch Free State commander led his storming party to that passage. It was rather steep and very narrow, and only two men could mount abreast, and it so happened that one of the Basutos, taking cover behind a rock just above this narrow place, was able to shoot the leading soldier at the head of the column endeavouring to make his way up. The soldier fell, and in falling knocked down the man behind him. That gave a temporary check to the column. The Basutos above, taking courage, rushed forward, and, by their impact, drove the Dutchmen down. Thaba Bosiyo was saved, and with it the independence of the Basuto nation was saved. Otherwise it would have fallen under the power of the Free State. This incident prolonged its life as an independent native community until in later days Moshesh put himself and his people under the protection of England. They are now the most contented and flourishing 
native people in South Africa. That breach in the sandstone precipice was made by a dyke of igneous rock which traversed the cliff and then, like the dyke at Syracuse, proceeded itself to decay, and in decaying left a free passage from the bottom up to the top of Thaba Bosiyo.

I pass away from the subject of geology to call your attention to the fact that some knowledge of botany provides another fertile source of interest to the traveller. He who has even an elementary acquaintance with geographical botany and with the classification of the various families of plants will find such acquaintance adds a great deal to his pleasure in travelling. Some families of plants are most frequently found under certain conditions of soil and climate; some are richer in species useful for food, or for other economic purposes. When one has learnt to know these and become familiar with them in his own country, he will derive no small enjoyment, when he visits other countries, from recognizing his old friends in their flowers and trees and in making new friends among their flora, and also in fitting these new friends of the vegetable kingdom in among the families, other members of which he knows already. To find new types akin to but a little different from the types of the flora he has known at home is one of the keenest enjoyments the naturalist can have in travelling abroad. What has been called "The pleasure of Recognition" is a very real pleasure. It gives a zest to every excursion, especially to mountain excursions, and opens an inexhaustible field for fresh observation. Neither will I venture to say anything about zoology, except to observe that what has been said about botany holds true of the animal kingdom also. If you have already some knowledge of the families of animals and their relations, it becomes very instructive to see the wild creatures of other countries. Unfortunately, the great mammals are becoming rather rare, and it was quite time that strenuous efforts should be made, as they have recently been made, to preserve the rare and large fauna of those parts of the world in which we hold control, such as Central Africa and South Africa. Some of the most interesting species were on the point of being extinct when these laws were introduced. There is a department of zoology to which it is not necessary to refer in detail -a department which we have not to go and look for, because it comes to us : it is that of the very small insect fauna, whether they have wings or not, and whether the latter class progress by creeping or by jumping. We have now learnt that they play a great part in the dissemination of disease.

From the field of nature we may now pass on to the other department in which a man can prepare himself by study for travel, namely, the things which belong to man and to the works of man. The relation of nature to human development, the influence which natural environment has upon the progress of civilization and on all the arts which belong to civilization, is an enormous theme on which one might discourse for days or even weeks; I only indicate to you what profit the historian, and especially the historian who has devoted himself to the 
study of the earlier stages in man's growth and development, finds in examining in one country after another the relations which exist between natural environment and the progress of human communities.

Every art, every science, every form of political life, every kind of industry, can be brought into connection in some way or other with the natural aptitudes or features of a country, except perhaps two. No philosopher, or man of science, or geographer seems to have succeeded in establishing a true organic relation between geographical conditions and the development in a nation either of metaphysics or of music. These two things seem to be entirely independent of anything natural conditions can do for their rise or progress, as you may find by observing that they flourish in very few countries and in countries presenting dissimilar conditions. Very few nations have produced musical composers of the first order, and very few are rich in executants of brilliant talent. In Germany, one used to be told that all the good musical bands, both military and civilian, came from Saxony, and that neither the Bavarians in the south nor the Prussians in the north had anything like the same gifts as executants. Some great composers have, however, come thence. In the Austrian Empire, the military bands consist, so one used to be told, almost entirely of men from Bohemia, probably most of them Czechs, not Germans. In Hungary, the wandering bands which supply music to the nation are neither Magyars nor Slavs, but almost entirely gipsies.

He whose journeys lead him among savage or semi-civilized peoples does well to acquire, before he sets out, some knowledge of primitive folklore, for he will find opportunities both of discovering how much of it still remains, and of adding to the stock of information already collected. Even now, after all that has been done by the distinguished author of the 'Golden Bough,' you can find for yourself little new pieces of antique superstition that strike you with surprise and that give one almost the pleasure of discovery. I remember in South Africa, when our party was going to cross a district supposed to be very full of lions, a kindly native came up and pressed upon us a charm. It consisted of a small rude figure of a lion. The remedy was to act homœopathically by keeping off the attacks of possible lion enemies. To collect the traditions of native races and compare them with those of other races, to induce them sing or chant their ancient ballads or legends, is one of the delights of travel, though it is one now seldom attainable and likely ere long to disappear as the legends pass out of memory. I do not think I ever enjoyed any incident in travel more than when once on the shores of the island of Tahiti a local chieftain brought together for our party a large number of the natives of the neighbourhood who sang in a sort of recitative some of the ancient chants recounting the exploits of warriors of old time, long before any European touched the island. Such vanishing relics of a departing world leave a profound impression.

And this brings me back to one of the many lights which travel enables 
us to throw upon history, if the traveller carries enough history in his mind to observe the facts of to-day with a historic eye. The folklore and the social usages of Kafirs or Polynesians often throw light on early European customs and superstitions. The racial changes in progress today illustrate the process by which races were formed in prehistoric times. The ancient races and their customs and their habits are in many regions vanishing and in others suffering change. There are processes going on in the Pacific islands which will probably have in forty years completely altered them and destroyed half their charm. In many isles diseases brought by Europeans are exterminating the native stock. In others the Chinese have come in; they are intermarrying with the natives, and in two generations more there will bardly be such a thing as a pure native left if the Chinese migration continues at its present rate. Fortunate is he who arrives still in time to see the remains of those ancient races still living as they lived before either the European, with his masterful ways, or the restlessly active Chinese broke in upon their genial easy-going simplicity.

However, I must pass on to the last topic for which I have time this evening. It is the profit and pleasure that may be derived from the study of architecture in travel. A little preliminary study, for no great amount of knowledge is needed, of the history of architecture, of the various styles and of the processes of transitions through which architecture has passed, adds enormously to the enjoyment of journeys in most parts of Europe and in Western Asia-one might almost say in all the old countries. In the new countries, Siberia, Australia, and the two Americas, there is, of course, very much less of interest to be seen. I am going to show you a few slides to illustrate the growth and progress of architectural design from the older forms of the ancient classical world down to times comparatively recent, though I regret not to have any slides to show how the typically ponderous grandeur of the earliest buildings we know, the temples of Egypt, has been reproduced in the most imposing recent building of the New World, the huge station of the Pennsylvania railway in New York.

[The slides shown were as follows: Interior of the ancient church of San Clemente at Rome, a basilica church of the early type (the oldest part fourth century); the church called the Abbaye aux Femmes at Caen, supposed to have been built by the wife of William the Conqueror (early Romanesque type); Fécamp Abbey Church in Normandy (Romanesque); the Temple Church in London; Cathedral of Laon in France (later Romanesque); Cathedral of Chartres in France (Pointed, fourteenth century); Cathedral of Burgos, in Spain (Pointed, fourteenth century); Interior of Notre Dame, Paris; Belfry tower of Bruges (fifteenth century); Church of S. Maria Della Salute (Venice); Pisani Palace (Venice); Antwerp Town Hall (all three Renaissance).]

The interest of the views just shown you lies in the fact that each style is associated with the character of the people that raised the building at the time when it was raised, and that you can trace in the changing 
styles the change in their material conditions and in their taste. One can usually determine (within a few years) the date of a church or a town hall from its style, until we come down to the nineteenth century, when styles got mixed and men began to build in the styles of past ages, having none of their own.

There are many other points connected with the history of architecture, and the light which it throws upon history, I should gladly have dwelt upon if time had permitted. For instance, it is very often the most visible indication of the relations that historically existed between different countries. Those of you who know the architecture of Scotland know how constantly the French forms reappear in the Scottish buildings of the (late) fifteenth and sixteenth centuries. And in the same way, architecture often reveals in the most direct and effective way the character of a race. There is in all the churches and many of the castles which the Normans built, whether in England or in France or in Sicily, the same character-an indication of indomitable force and strength which belonged to the Normans conspicuously above every other race of Europe.

It only remains to say that besides all these sources of pleasure which a man may derive from carrying along with him as he travels some know. ledge of history, some trained power of observation, and some elementary knowledge of the sciences of nature that are easiest to learn, besides all these there is the instruction and stimulus to thought which one may derive from studying the temper and mind and ideas of the peoples with whom one comes in contact. First of all great travellers is the hero of the Odyssey. The poet says of him that he was one who "saw the cities and knew the mind of many men." * To know the minds of many men, that is to say, to study the character and idiosyncrasy of nations through individuals, is the most interesting of all the things travel enables us to do, and for that study we require two preparations-some knowledge of history and some knowledge of languages. When one goes into the remoter regions linguistic knowledge is a thing hard to obtain. For most of us life is too short to learn Arabic or Chinese or Japanese, or even an easy tongue like Hindustani, and, of course, one suffers proportionately in travelling in the countries where these are spoken. Every one, however, may with a little trouble get a working knowledge of Italian and Spanish and German. Russian, however, takes a good deal of labour, though it repays the labour. To get really acquainted with the mind of a people one must travel slowly. Little is learnt by him who is whirled about in a train or motor. Far better travel on foot or on a bicycle or in a light carriage-an excellent mode of locomotion, staying at the small country inns, and stopping on the road to talk to the peasants and getting into some sort of touch with their lives. I am afraid that in the modern passion for haste, we are losing that greatest benefit of travel which consisted of knowing how to enter into the thoughts and tastes

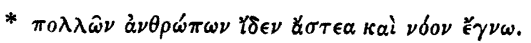


of other peoples, how to see them sympathetically, and understand the lines on which their minds move. That extreme swiftness and ease of communications, which we value because it enables us to go so far and see so much in a limited time, has its inevitable drawbacks. It makes us live in hurry, and to be in a hurry is to be superficial. You may remember that in a lecture the Society had the pleasure of hearing some eight months ago from Mr. Rudyard Kipling, he observed that travel would in the near future be very much swifter, because transportation to places far away would be chiefly by aeroplanes. If we have not reached that stage yet (and some of us do not desire to reach it) we are at any rate all getting into the habit of travelling so fast that a good deal of the old pleasure and profit is being lost. Perhaps we must look forward to a time when the world will become so thoroughly well known that most of the mystery and romance which it has been our own privilege to enjoy, and which our forefathers enjoyed even more fully, will have disappeared. In the next three generations the world will have come to seem very small. When a man has crossed the Atlantic ocean twice or thrice it no longer strikes the imagination with the same sense of awe and wonder as it used to do when he gazed out over its heaving billows from some height in Cornwall or the rocky heights of Ireland, knowing nothing of the shores that lay beyond. Even the vast Pacific is not quite solemn and does not seem quite so vast to those who have traversed it in several long voyages. When we think how enormously our own knowledge of the world has grown during the last three centuries we may well suppose that two centuries hence there will be hardly any part of the Earth which will not have become as familiar to everybody who cares for travel as France and Italy are to us now. And, therefore, we may feel inclined to pity our successors, to whom travel will give fewer of the charms of novelty. Yet, on the other hand, it may well be that our successors will have different tastes and different sources of joy from those which we possess. If they discover new sources, new fountains of delight, they will not have to regret those that have been ours and will be less completely theirs. One way or another, some enjoyment there will surely always be in travel. Some human capacities and powers do remain unchanged. What we see and hear every day proves that human courage is as great and human firmness in facing death as unshakeable as ever they were in previous ages, and thus, amid the sadness and strain of these months of effort and of mourning there rises in us a fresh sense of the inexhaustible virility of an ancient race. So also may we feel sure that the love of beauty and the love of knowledge will always remain to be a source of delight to mankind. They are as strong now as they were thirty centuries ago, and they may remain so for ever.

The Presinent (before the paper): It is very pleasing to me to think that my task to-night is virtually a sinecure, for to introduce Lord Bryce to any assembly of Englishmen is quite unnecessary; and the same thing might be said of any assembly 